\title{
Effects of exogenous glucose and sucrose on photosynthesis in triticale seedlings under salt stress
}

\author{
L.H. WANG, G.L. LI, S. WEI, L. J. LI, S.Y. ZUO, X. LIU, W.R. GU, and J. LI ${ }^{+}$ \\ College of Agriculture, Northeast Agricultural University, Harbin 150030, Heilongjiang Province, China
}

\begin{abstract}
Salinization disturbs metabolic processes of plants and results in reduced growth and productivity. In our study, the Dongnong 8809 variety of triticale ( $\times$ Triticosecale Wittmack) was evaluated for its physiological responses to salt stress during the seedling stage. We evaluated biomass production, relative chlorophyll content, chlorophyll fluorescence, and leaf gas-exchange parameters. Our results indicated that salt stress greatly reduced matter accumulation, SPAD value, photosynthetic capacity. However, seedlings treated with exogenous sugars showed significantly enhanced matter accumulation, SPAD value, quantum yield of PSII, electron transport rate, net photosynthetic rate, decreased stomatal limitation value, and improved photosynthetic capacity compared to seedlings treated with salt stress alone. Exogenous glucose and sucrose can alleviate the inhibitory effect of salt stress on the growth of triticale, and of the two exogenous sugars, sucrose had a stronger alleviating effect than that of glucose under salt stress.
\end{abstract}

Additional key words: exogenous sugar; growth; photosynthesis; tolerance.

\section{Introduction}

Triticale ( $\times$ Triticosecale Wittmack) is a cereal crop cultivar obtained by cross-fertilization of wheat (Triticum spp.) and rye (Secale spp.) (Rasouli and Kiani-Pouya 2015) that offers high forage production and is an important potential protein source for animal feed (Samad and Karmoker 2013). Climate-resilient crops such as triticale are important for food production.

Salinization has become a major concern throughout the world (Liu et al. 2015) and especially in China (Sharathchandra et al. 2016). More than 7\% of the world land is salt-affected (Liang et al. 2005, Setia et al. 2013), especially, land in arid and semiarid regions (Bray et al. 2000). Salt stress affects plant growth and productivity during all developmental stages (Akram et al. 2011). The introduction and utilization of salt-tolerant crop plants is one of the most efficient and useful ways to cope with salt stress in these regions. Seed germination represents the primary period of plant growth, and at this stage, salt stress affects triticale most seriously. Since the photosynthetic activity of plants is inefficient during this phase, the ionic effect of salt stress is the dominant factor during the germination. Later, in young seedlings, the salt stress can lead to serious stomatal closure in leaves and a reduction of plant water potential; as a result, growth rate and production decline (Teng et al. 2012, Hu et al. 2013).

Sugar is indispensable in the life cycle of plants; it provides plants with energy and participates in the synthesis of the cell wall but also acts as a primary messenger. Sugars, such as glucose, sucrose, trehalose, and fructose, participate in many signaling, regulatory, and metabolic pathways in plants (Smeekens et al. 2009, Trouvelot et al. 2014). These pathways include biotic stress resistance; for instance, the exogenous application of trehalose has been shown to enhance the resistance of wheat (Triticum aestivum L.) against powdery mildew caused by Blumeria graminis (Reignault et al. 2001, Muchembled et al. 2006, Tayeh et al. 2014). Glucose acts as a direct signaling molecule in plant metabolism and is closely related to phytohormones. If excessive glucose is supplied to the external environment of the seedlings, the growth of the seedlings is stopped and the differentiation is interrupted, the cotyledons cannot expand and turn yellow. This phenomenon may be related to the increase of abscisic acid (ABA). Garg et al. (2002) found that glucose functions as a compatible solute in stabilization of biological structures under abiotic stress in bacteria, fungi, and invertebrates. Sucrose can reduce the water potential of the cells to resist adverse environments. Baque et al. (2011) also found that $5 \%$ sucrose supply was ideal for the production of root dry mass in Periploca sepium Bunge, but higher sucrose

\footnotetext{
$\overline{\text { Received }} 18$ October 2017, accepted 16 August 2018.

${ }^{+}$Corresponding author; phone: +86 13204513712; fax:+86-451-55190447; e-mail: jingli1027@163.com

Abbreviations: $\mathrm{ABA}$ - abscisic acid; Chl-chlorophyll; $C_{\mathrm{i}}$ - intracellular $\mathrm{CO}_{2}$ concentration; $E$-transpiration rate; ETR-electron transport rate; $F_{0}$ - minimal fluorescence yield of the dark-adapted state; $F_{0}{ }^{\prime}-$ minimal fluorescence yield of the light-adapted state; $F_{m}-$ maximal fluorescence yield of the dark-adapted state; $\mathrm{F}_{\mathrm{m}}{ }^{\prime}$ - maximal fluorescence yield of the light-adapted state; $\mathrm{F}_{\mathrm{s}}$-steady-state fluorescence yield; $\mathrm{F}_{\mathrm{v}} / \mathrm{F}_{\mathrm{m}}-$ maximum quantum yield of PSII photochemistry; $\mathrm{F}_{\mathrm{v}} / \mathrm{F}_{0}$ - potential photochemical efficiency; $g_{\mathrm{s}}-$ stomatal conductance; $\mathrm{L}_{\mathrm{s}}-$ stomatal limitation value; NPQ - nonphotochemical quenching; $P_{\mathrm{N}}$ - net photosynthetic rate; $\mathrm{q}_{\mathrm{P}}$ - photochemical quenching coefficient; WUE water-use efficiency; $\mathrm{WUE}_{\mathrm{i}}$ - intrinsic water-use efficiency; $\mathrm{Y}$ - quantum yield of PSII.

Acknowledgements: This work was funded and supported by Key Research and Development Program of $13^{\text {th }}$ Five-Year No. 2017YFD0300405.
} 
concentrations inhibited the accumulation of root dry mass. The sugar-mediated repression of photosynthesis is among the general mechanisms that maintain photosynthetic homeostasis over a wide range of growing conditions (Mortain-Bertrand et al. 2008).

Since the area of saline soils in the world continues to increase (Munns 2002, Arzani 2008), studies on the effects of combined stress factors seem to be of great importance. In contrast to the large body of work that has focused on the effect of trehalose on photosynthesis (Pego et al. 2000, Gibson 2005, Araya et al. 2006), few studies have been performed on the effects of glucose and sucrose on photosynthesis in triticale seedlings under salt stress. Thus, the role of glucose and sucrose in salt tolerance must be examined further. In this study, we investigated the response of triticale seedlings to salt stress and sugar pretreatment in terms of growth and photosynthetic characteristics. We hope to reveal roles of glucose and sucrose in increasing triticale tolerance to salt stress and show that osmoregulators, such as glucose and sucrose, can be used to protect plants against hostile environmental conditions.

\section{Materials and methods}

Plant material and experimental design: Dongnong 8809 was chosen as the experimental materials, and triticale seeds were supplied by the Physical and Culture Research Center of Wheat at Northeast Agricultural University, China. Triticale seeds were chosen for their similar size and no damage, and then they were surfacesterilized according to Samad and Karmoker (2012). After sterilization, the seeds were placed in a computercontrolled incubator and kept in the dark at a temperature of $25^{\circ} \mathrm{C}$ to facilitate germination. Germinated triticale seeds with the same shoot length were moved to a $H P G$ $280 H X$ phytotron (East Union Hall, China) with day/ night temperatures of $25 \pm 2{ }^{\circ} \mathrm{C} / 20^{\circ} \mathrm{C} \pm 2{ }^{\circ} \mathrm{C}$, day/night length of $12 / 12 \mathrm{~h}$, and relative humidity of $60-80 \%$. After germination, the seedlings were grown in half-strength Hoagland nutrient solution for $8 \mathrm{~d}$ (the seedlings had two leaves). Then they were treated with $0.5 \mathrm{mmol} \mathrm{L}^{-1}$ sucrose, or $0.5 \mathrm{mmol} \mathrm{L}^{-1}$ glucose or $0.5 \mathrm{mmol} \mathrm{L}^{-1}$ mannitol dissolved in half-strength Hoagland nutrient for $3 \mathrm{~d}$. After pretreatment, the solution was changed to normal growth (in half-strength Hoagland nutrient) solution with or without $100 \mathrm{mM} \mathrm{NaCl}$, after which the seedlings were left to grow for $6 \mathrm{~d}$. At the end of the experiments, seven types of treatment were evaluated: the control (CK) without treatments, glucose-pretreated $(\mathrm{G})$, sucrose-pretreated $(\mathrm{T})$ seedlings, salt-treated (S), glucose-pretreated, and salttreated $(\mathrm{G}+\mathrm{S})$, sucrose-pretreated and salt-treated $(\mathrm{T}+\mathrm{S})$, and mannitol-pretreated and salt-treated $(\mathrm{M}+\mathrm{S})$ seedlings. Three replicates were used in each treatment, one hundred seeds were prepared in each replicate. After germination, we had to eliminate seeds, which did not germinate and showed shoot length inconsistency, and select the better growing seeds to grow in the computer-controlled incubator. The remaining seeds included three replicates per treatment, sixty seeds per replicate.
Biomass production: For each of the seven treatments, ten seedlings treated for $6 \mathrm{~d}$ were taken. The aboveground and underground parts were separated, and each was washed with distilled water and dried with filter paper. Then, the fresh samples were weighed, and the ratios of shoots to roots were calculated. The fresh samples were de-enzymed at $105^{\circ} \mathrm{C}$ for $15 \mathrm{~min}$ in a drying oven and then dried at $80^{\circ} \mathrm{C}$ for $48 \mathrm{~h}$. Then, the dry matter mass was determined.

Photosynthetic characteristics: All photosynthetic parameters were determined using the middle part of the second fully expanded leaf, avoiding the leaf vein on the sixth day of the treament with or without salt between 9:00 and 12:00 $\mathrm{h}$ in sunny weather. Ten replicates were used in each treatment.

SPAD values were determined with a CCM-200plus SPAD chlorophyll (Chl) content meter (Opti-Sciences, USA). The result of these measurements was displayed digitally as the so-called SPAD units. The value of these units is proportional to the $\mathrm{Chl}$ content of the analyzed leaf surface $\left(6 \mathrm{~mm}^{2}\right)$ (Monje and Bugbee 1992).

Chl fluorescence parameters were determined with a PAM-2500 Chl fluorometer (Walz, Germany). After a 20-min dark-adaptation period, the initial $\left(\mathrm{F}_{0}\right)$ and maximum fluorescence $\left(\mathrm{F}_{\mathrm{m}}\right)$ were determined. Immediately, the leaves were exposed to an actinic irradiation of $447 \mu \mathrm{mol}$ (photon) $\mathrm{m}^{-2} \mathrm{~s}^{-1}$ for $30 \mathrm{~min}$ to measure steady-state Chl $a$ fluorescence $\left(\mathrm{F}_{\mathrm{s}}\right)$, saturating pulses $\left[3,000 \mu \mathrm{mol}\right.$ (photon) $\left.\mathrm{m}^{-2} \mathrm{~s}^{-1}\right]$ were applied to determine the maximum florescence $\left(\mathrm{F}_{\mathrm{m}}{ }^{\prime}\right)$. Eventually, leaves were illuminated with far-red radiation to determine the minimal fluorescence $\left(\mathrm{F}_{0}{ }^{\prime}\right)$. Other parameters were calculated as follows: maximal photochemical efficiency of PSII, $\mathrm{F}_{\mathrm{v}} / \mathrm{F}_{\mathrm{m}}=\left(\mathrm{F}_{\mathrm{m}}-\mathrm{F}_{0}\right) / \mathrm{F}_{\mathrm{m}}$, potential photochemical efficiency, $\mathrm{F}_{\mathrm{v}} / \mathrm{F}_{0}=\left(\mathrm{F}_{\mathrm{v}} / \mathrm{F}_{\mathrm{m}}\right) /\left(1-\mathrm{F}_{\mathrm{v}} / \mathrm{F}_{\mathrm{m}}\right)$, actual photochemical efficiency of PSII in the light, $\mathrm{Y}_{(\mathrm{II})}=\left(\mathrm{F}_{\mathrm{m}}{ }^{\prime}-\mathrm{F}_{\mathrm{s}}\right) / \mathrm{F}_{\mathrm{m}}{ }^{\prime}$ (DemmigAdams 1996), photochemical quenching coefficient, $\mathrm{q}_{\mathrm{P}}=$ $\left(\mathrm{F}_{\mathrm{m}}{ }^{\prime}-\mathrm{F}_{\mathrm{s}}\right) /\left(\mathrm{F}_{\mathrm{m}}{ }^{\prime}-\mathrm{F}_{0}{ }^{\prime}\right)$; nonphotochemical quenching coefficient, $N P Q=\left(F_{m}-F_{m}{ }^{\prime}\right) / F_{m}{ }^{\prime}$, apparent photosynthetic electron transport rate, $\mathrm{ETR}=\mathrm{PPFD} \times 0.84 \times 0.5 \times \Phi_{\mathrm{PSII}}$ (Maxwell and Johnson 2000, Baker 2008).

Different photosynthetic parameters, such as net photosynthetic rate $\left(P_{\mathrm{N}}\right)$, transpiration rate $(E)$, stomatal conductance $\left(g_{\mathrm{s}}\right)$, leaf internal $\mathrm{CO}_{2}$ concentration $\left(C_{\mathrm{i}}\right)$, and atmospheric $\mathrm{CO}_{2}$ concentration $\left(C_{\mathrm{a}}\right)$, were determined with a CI-340 hand-held photosynthesis system ( Walz, Germany). The instantaneous water-use efficiency (WUE) was calculated as $P_{\mathrm{N}} / E$, and the intrinsic water-use efficiency ( $\mathrm{WUE}_{\mathrm{i}}$ ) was determined as $P_{\mathrm{N}} / g_{\mathrm{s}}$. The stomatal limitation value $\left(\mathrm{L}_{\mathrm{s}}\right)$ was defined as $1-C_{\mathrm{i}} / C_{\mathrm{a}}$ (Yin et al. 2006). All photosynthetic measurements were taken at a saturating incident PPFD of $700 \mu \mathrm{mol}$ (photon) $\mathrm{m}^{-2} \mathrm{~s}^{-1}$. The temperature was $25 \pm 2{ }^{\circ} \mathrm{C}$ and the concentration of $\mathrm{CO}_{2}$ was $400 \pm 5 \mu \mathrm{mol} \mathrm{L}{ }^{-1}$.

Statistical analysis: Experimental data are expressed as the mean with standard deviation. Statistical analysis was performed using SPSS 17.0 and Excel 2007, and all means were evaluated using Fisher's least significant difference 
(LSD) test at a significance level of $p<0.05$.

\section{Results}

Seedling growth: The growth of triticale seedlings showed significant differences between the seven treatments (Fig. 1). Without salt stress, compared to CK, T seedlings were in significantly better conditions, but $\mathrm{G}$ seedlings were more yellowish than that of $\mathrm{CK}$, maybe the concentration of glucose was too high and stopped grow and differentiation. These results showed that sucrose can promote the growth of triticale seedlings, and glucose had a inhibiting effect at the high concentration.

Under salt stress, seedlings were weak, yellowish, and in a bad condition. Salt significantly affected the growth of the seedlings and caused serious lodging. However, seedlings pretreated with glucose and sucrose were not weak and maintained strong growth under saline conditions. Compared to $\mathrm{S}$, seedlings pretreated with mannitol were stronger. But seedlings pretreated with mannitol were more yellowish than seedlings pretreated with glucose and sucrose under salt stress.

Biomass production: Compared with $\mathrm{CK}$, the total dry mass of triticale in the $\mathrm{G}$ and $\mathrm{T}$ increased by 41.4 and $34.4 \%$, and the total fresh mass increased by 59.7 and $65.7 \%$, respectively, showing that glucose and sucrose pretreatments promoted the growth of triticale. The root/ shoot ratios of $\mathrm{G}$ and $\mathrm{T}$ increased compared to $\mathrm{CK}$.

Compared with those in $\mathrm{CK}$, the total dry mass and total fresh mass of triticale in $\mathrm{S}$ decreased by 60.9 and
$55.5 \%$, respectively. The total dry mass of $\mathrm{G}+\mathrm{S}$ and $\mathrm{T}+\mathrm{S}$ were 3.91 and 3.34 times as high as those of $\mathrm{S}$, while the total fresh mass $\mathrm{G}+\mathrm{S}$ and $\mathrm{T}+\mathrm{S}$ were 3.04 and 3.03 times as high as those of S. All growth parameters of the seedlings increased in $\mathrm{G}+\mathrm{S}$ and $\mathrm{T}+\mathrm{S}$ compared to $\mathrm{S}$. Compared to $\mathrm{S}$, the dry mass and fresh mass of the shoot and the root of $\mathrm{G}+\mathrm{S}$ and $\mathrm{T}+\mathrm{S}$ increased. while the differences in dry mass and fresh mass of the shoot and the root between $\mathrm{M}+\mathrm{S}$ and $\mathrm{S}$ were not significant. The root/shoot ratios of $\mathrm{G}+\mathrm{S}$ and $\mathrm{T}+\mathrm{S}$ greatly increased compared to $\mathrm{S}$. These results showed that salt stress significantly inhibited the growth of plants. Exogenous glucose and sucrose can enhance the salt resistance of plants and promote growth and dry matter accumulation. The same concentration of mannitol did not cause this effect, showing that the ameliorating effect of exogenous sugar on salt stress is not because of osmosis.

SPAD value: Chl contents are highly correlated with SPAD, thus, the changes in SPAD represent changes in the Chl content. Compared with CK, SPAD value increased in $\mathrm{G}$ by $41 \%$ at the sixth day, and SPAD value increased in $\mathrm{T}$ by $31 \%$ at the sixth day. It showed that glucose and sucrose can increase the Chl content in triticale (Fig. 2). SPAD values decreased with the application of salt. Compared with CK, SPAD values were lower in S by $13 \%$. The pretreatment of glucose and sucrose could change the decline caused by salt. Compared to S, SPAD values were higher in $\mathrm{G}+\mathrm{S}$ and $\mathrm{T}+\mathrm{S}$ by 52 and $53 \%$, respectively, and SPAD values in $\mathrm{M}+\mathrm{S}$ were similar to $\mathrm{S}$. These results showed that glucose and sucrose pretreatment could alleviate the Chl decline caused by salt stress and help
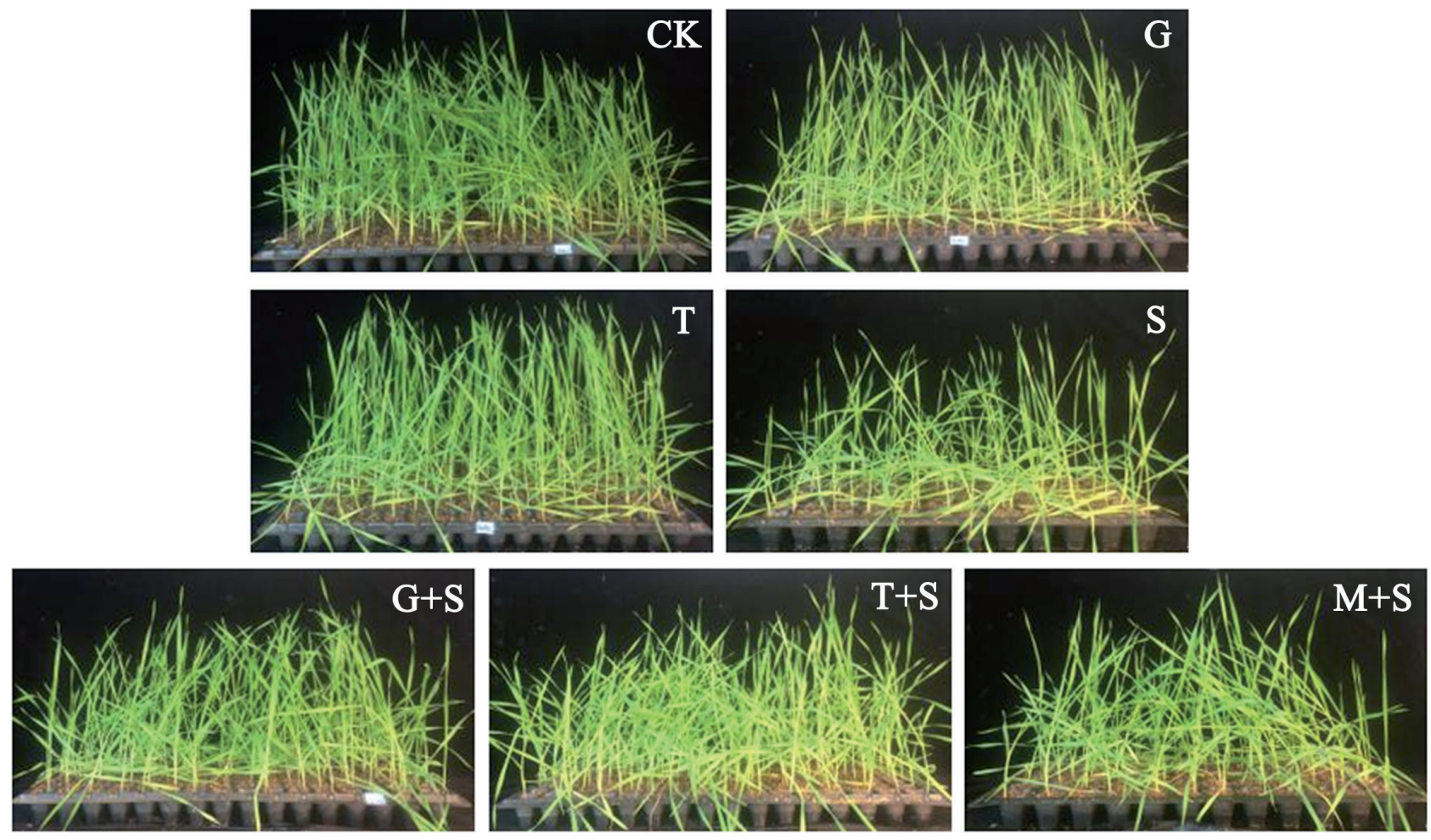

Fig.1. Effect of seven different treatments on the growth of triticale seedlings. 
maintain normal photosynthesis. Mannitol did not show this effect.

Chl fluorescence: Compared with $\mathrm{CK}, \mathrm{F}_{0}$ was higher in $\mathrm{G}$ and $\mathrm{T}$, while $\mathrm{q}_{\mathrm{P}}, \mathrm{NPQ}, \mathrm{Y}$, and ETR were lower in $\mathrm{G}$ and $\mathrm{T}$, and the reduction of $\mathrm{q}_{\mathrm{P}}, \mathrm{NPQ}, \mathrm{Y}, \mathrm{ETR}$ in $\mathrm{G}$ were higher than that of $\mathrm{T}$. Compared with $\mathrm{CK}, \mathrm{F}_{\mathrm{v}} / \mathrm{F}_{\mathrm{m}}$ was higher in $\mathrm{G}$ and lower in $\mathrm{T}$, while $\mathrm{F}_{\mathrm{m}}$ was higher in $\mathrm{T}$. Compared with $\mathrm{CK}, \mathrm{F}_{0}$, and NPQ were higher in $\mathrm{S}$ by 12 and $25 \%$, respectively (Table 2 ). $\mathrm{F}_{\mathrm{m}}, \mathrm{F}_{\mathrm{v}} / \mathrm{F}_{\mathrm{m}}, \mathrm{q}_{\mathrm{p}}$, Y, ETR were lower in $\mathrm{S}$, the reduction of $\mathrm{q}_{\mathrm{p}}, \mathrm{Y}$, ETR was 17,26 , and $29 \%$, respectively. Compared to $\mathrm{S}, \mathrm{F}_{0}$ was lower in $\mathrm{G}+\mathrm{S}, \mathrm{T}+\mathrm{S}$, and $\mathrm{M}+\mathrm{S}$, while $\mathrm{F}_{\mathrm{v}} / \mathrm{F}_{\mathrm{m}} . \mathrm{q}_{\mathrm{P}}$, Y, ETR were higher in $\mathrm{G}+\mathrm{S}$, $\mathrm{T}+\mathrm{S}, \mathrm{M}+\mathrm{S}$. Compared to $\mathrm{S}$, the increment of $\mathrm{q}_{\mathrm{p}}$ in $\mathrm{G}+\mathrm{S}$ and $\mathrm{M}+\mathrm{S}$ was equal, the increment of $\mathrm{Y}$ in $\mathrm{M}+\mathrm{S}$ was higher than that of $\mathrm{G}+\mathrm{S}$ and $\mathrm{T}+\mathrm{S}$, the increment of ETR in $\mathrm{G}+\mathrm{S}$, $\mathrm{T}+\mathrm{S}$ and $\mathrm{M}+\mathrm{S}$ was 13,18 , and $4 \%$, respectively. Compared to $\mathrm{S}, \mathrm{F}_{\mathrm{m}}$ was higher in $\mathrm{G}+\mathrm{S}, \mathrm{T}+\mathrm{S}$ and lower in $\mathrm{M}+\mathrm{S}$, while NPQ was higher in $\mathrm{M}+\mathrm{S}$ and lower in $\mathrm{G}+\mathrm{S}$ and $\mathrm{T}+\mathrm{S}$.

Leaf gas-exchange parameters: Compared with $\mathrm{CK}, P_{\mathrm{N}}$, $g_{\mathrm{s}}, C_{\mathrm{i}}$, and WUE were higher and $E, \mathrm{~L}_{\mathrm{s}}$ were lower in $\mathrm{G}$ and T. In $\mathrm{G}, g_{\mathrm{s}}, E$, and $\mathrm{L}_{\mathrm{s}}$ were higher than that in $\mathrm{T}$, while $P_{\mathrm{N}}$,
$C_{\mathrm{i}}$, WUE, and $\mathrm{WUE}_{\mathrm{i}}$ were lower in $\mathrm{G}$ than that in $\mathrm{T}$. Compared with CK, $P_{\mathrm{N}}, g_{\mathrm{s}}, C_{\mathrm{i}}, E$, WUE, $\mathrm{WUE}_{\mathrm{i}}$ were lower in $\mathrm{S}$, while $\mathrm{L}_{\mathrm{s}}$ was higher in $\mathrm{S}$. Compared to $\mathrm{S}, P_{\mathrm{N}}, g_{\mathrm{s}}, C_{\mathrm{i}}$, $E$, WUE, and $\mathrm{WUE}_{\mathrm{i}}$ were higher in $\mathrm{G}+\mathrm{S}, \mathrm{T}+\mathrm{S}$, and $\mathrm{M}+\mathrm{S}$ (Table 3). The increase of these parameters in $\mathrm{M}+\mathrm{S}$ was smaller than that of $\mathrm{G}+\mathrm{S}$ and $\mathrm{T}+\mathrm{S}$. $\mathrm{L}_{\mathrm{s}}$ in $\mathrm{G}+\mathrm{S}, \mathrm{T}+\mathrm{S}$, and $\mathrm{M}+\mathrm{S}$ were lower than that of $\mathrm{S}$; the difference between $\mathrm{G}+\mathrm{S}$ and $\mathrm{M}+\mathrm{S}$ was not significant, while $\mathrm{L}_{\mathrm{s}}$ in $\mathrm{T}+\mathrm{S}$ showed a small drop.

Relationships between biomass production and photosynthetic characteristics: A correlation analysis was performed between the different photosynthetic parameters and plant biomass (Table 4). For all treatments, the total dry mass (TDM) and the total fresh mass (TFM) showed positive correlations with $P_{\mathrm{N}}, g_{\mathrm{s}}, \mathrm{L}_{\mathrm{s}}$, WUE, $\mathrm{q}_{\mathrm{P}}$, NPQ, ETR, and Y, and the root-to-shoot ratio (R/S) showed negative correlations with these photosynthetic parameters.

In $\mathrm{CK}$, TDM showed a significant positive correlation with $P_{\mathrm{N}}, g_{\mathrm{s}}$, WUE, $\mathrm{q}_{\mathrm{P}}$, and NPQ, and TFM showed a significant positive correlation with $\mathrm{L}_{\mathrm{s}}$ and ETR. In $\mathrm{G}$ and T, TDM and TFM showed positive correlations with $P_{\mathrm{N}}$,

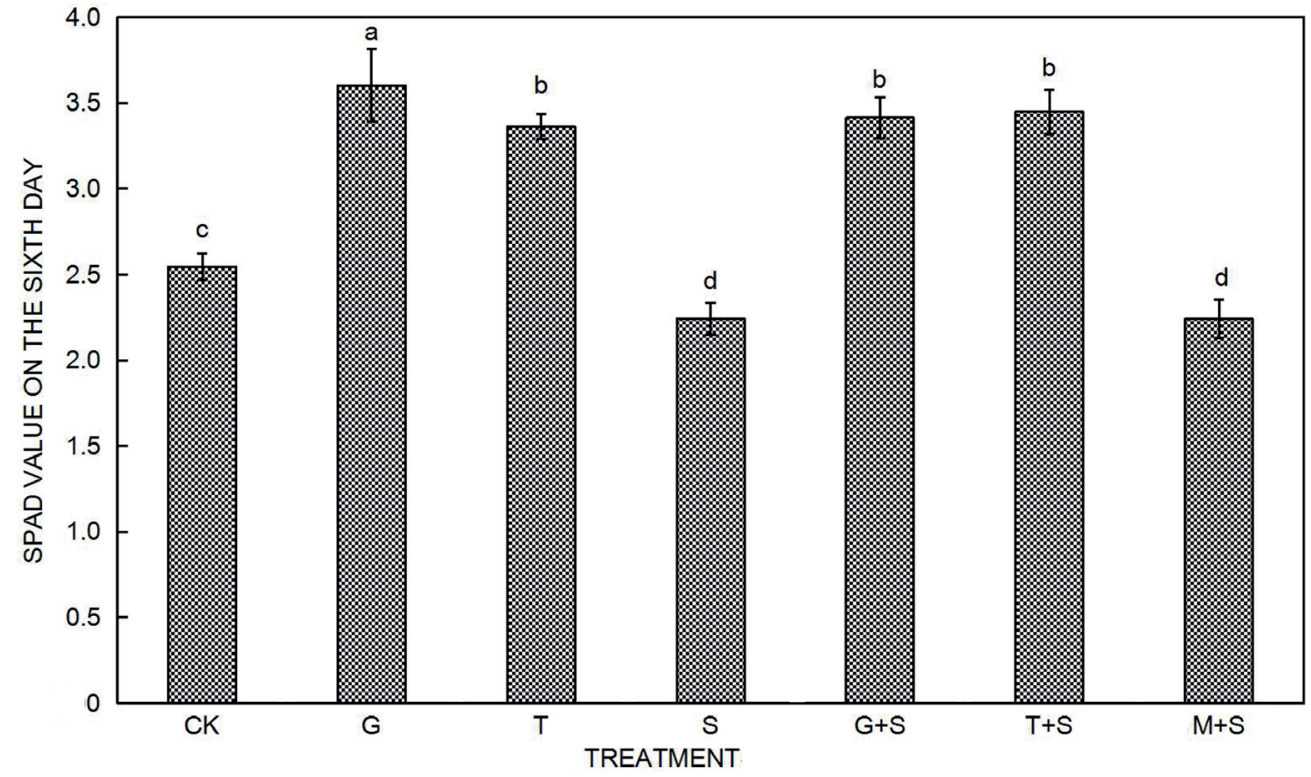

Fig. 2. Effects of seven treat-ments on SPAD value of triticale seedlings. CK - the control; G - glucosepretreated; $\mathrm{T}-$ sucrosepretreated; S - salt-treated; $\mathrm{G}+\mathrm{S}$ - glucose-pretreated and salt-treated; $\mathrm{T}+\mathrm{S}$ sucrose-pretreated and salt treated; $\mathrm{M}+\mathrm{S}$-mannitolpretreated and salt-treated.

Table 1. Effects of seven treatments on matter accumulation of triticale seedlings. ${ }^{\text {a }}$ Different letters in the same columns indicate significant difference between the treatments at 0.05 level. ${ }^{b}$ Data are mean $\pm \mathrm{SD} ; n=10$. $\mathrm{CK}-$ the control; $\mathrm{G}-$ glucose-pretreated; $\mathrm{T}$ - sucrose-pretreated; $\mathrm{S}$ - salt-treated; $\mathrm{G}+\mathrm{S}$ - glucose-pretreated and salt-treated; $\mathrm{T}+\mathrm{S}$ - sucrose-pretreated and salt treated; $\mathrm{M}+\mathrm{S}$ mannitol-pretreated and salt-treated.

\begin{tabular}{lcccc}
\hline $\begin{array}{c}\text { Treatment } \\
\text { Shoot fresh mass Root fresh mass } \\
{[\mathrm{g}]}\end{array} \quad \begin{array}{l}\text { Total fresh mass Shoot dry mass } \\
{[\mathrm{g}]}\end{array}$ & $\begin{array}{l}\text { Root dry mass } \\
{[\mathrm{g}]}\end{array}$ & $\begin{array}{l}\text { Total dry mass } \\
{[\mathrm{g}]}\end{array}$ & $\begin{array}{l}\text { Root-shoot ratio } \\
{[\mathrm{g}]}\end{array}$ \\
\hline $\mathrm{CK}$ & $0.2989 \pm 0.0100^{\mathrm{c}} 0.0388 \pm 0.0090^{\mathrm{cd}} 0.3377 \pm 0.0010^{\mathrm{c}} 0.0356 \pm 0.0030^{\mathrm{c}}$ & $0.0033 \pm 0.0000^{\mathrm{d}} 0.0389 \pm 0.0030^{\mathrm{c}} 0.1306 \pm 0.0345^{\mathrm{b}}$ \\
$\mathrm{G}$ & $0.4730 \pm 0.0100^{\mathrm{a}} 0.0662 \pm 0.0060^{\mathrm{ab}} 0.5392 \pm 0.0087^{\mathrm{a}} 0.0502 \pm 0.0010^{\mathrm{ab}} 0.0048 \pm 0.0000^{\mathrm{b}} 0.0550 \pm 0.0010^{\mathrm{ab}} 0.1401 \pm 0.0142^{\mathrm{b}}$ \\
$\mathrm{T}$ & $0.4793 \pm 0.0070^{\mathrm{a}} 0.0803 \pm 0.0104^{\mathrm{ab}} 0.5596 \pm 0.0096^{\mathrm{a}} 0.0468 \pm 0.0012^{\mathrm{b}}$ & $0.0055 \pm 0.0001^{\mathrm{a}} 0.0523 \pm 0.0013^{\mathrm{b}} 0.1676 \pm 0.0227^{\mathrm{ab}}$ \\
$\mathrm{S}$ & $0.1362 \pm 0.0030^{\mathrm{d}} 0.0142 \pm 0.0061^{\mathrm{e}} 0.1504 \pm 0.0076^{\mathrm{d}} 0.0128 \pm 0.0095^{\mathrm{d}} 0.0023 \pm 0.0001^{\mathrm{g}} 0.0152 \pm 0.0095^{\mathrm{d}} 0.1043 \pm 0.0445^{\mathrm{b}}$ \\
$\mathrm{G}+\mathrm{S}$ & $0.3990 \pm 0.0600^{\mathrm{b}} 0.0585 \pm 0.0248^{\mathrm{bc}} 0.4575 \pm 0.0847^{\mathrm{b}} 0.0555 \pm 0.0007^{\mathrm{a}} 0.0039 \pm 0.0000^{\mathrm{c}} 0.0594 \pm 0.0007^{\mathrm{a}} 0.1425 \pm 0.0401^{\mathrm{ab}}$ \\
$\mathrm{T}+\mathrm{S}$ & $0.3715 \pm 0.0400^{\mathrm{b}} 0.0843 \pm 0.0110^{\mathrm{a}} 0.4558 \pm 0.0290^{\mathrm{b}} 0.0482 \pm 0.0004^{\mathrm{b}} 0.0026 \pm 0.0001^{\mathrm{e}} 0.0508 \pm 0.0004^{\mathrm{b}} 0.2308 \pm 0.0548^{\mathrm{a}}$ \\
$\mathrm{M}+\mathrm{S}$ & $0.1379 \pm 0.0300^{\mathrm{d}} 0.0256 \pm 0.0158^{\mathrm{de}} 0.1635 \pm 0.0404^{\mathrm{d}} 0.0189 \pm 0.0007^{\mathrm{d}} 0.0024 \pm 0.0001^{\mathrm{f}} 0.0213 \pm 0.0008^{\mathrm{d}} 0.1851 \pm 0.0983^{\mathrm{ab}}$ \\
\hline
\end{tabular}



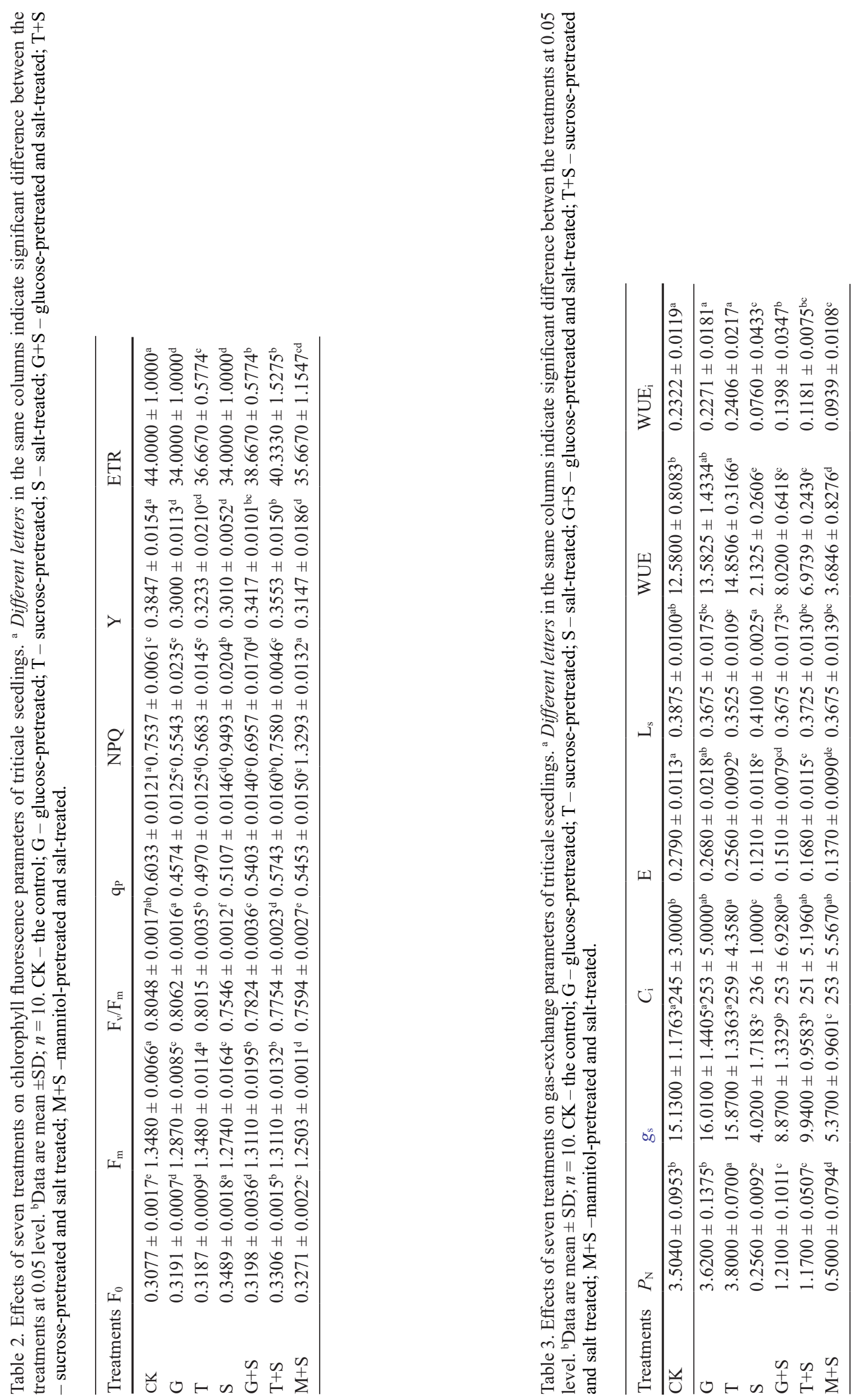
Table 4. Correlation coefficients among biomass, gas exchange, and chlorophyll fluorescence parameters in seven treatments of triticale

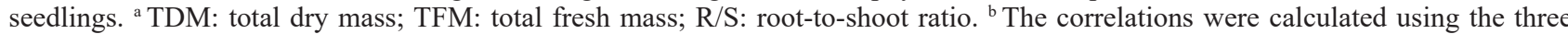
replicates of each treatment. ${ }^{c}$ Probabilities $(* P \leq 0.05 ; * * P \leq 0.01)$ are shown. $\mathrm{CK}$ - the control; $\mathrm{G}$ - glucose-pretreated; $\mathrm{T}-$ sucrosepretreated; $\mathrm{S}$ - salt-treated; $\mathrm{G}+\mathrm{S}-$ glucose-pretreated and salt-treated; $\mathrm{T}+\mathrm{S}$ - sucrose-pretreated and salt treated; $\mathrm{M}+\mathrm{S}-\mathrm{mannitol}-$ pretreated and salt-treated.

\begin{tabular}{|c|c|c|c|c|c|c|c|c|c|}
\hline Treatment & Parameter & $P_{\mathrm{N}}$ & $g_{\mathrm{s}}$ & $\mathrm{L}_{\mathrm{s}}$ & WUE & $\mathrm{q}_{\mathrm{P}}$ & NPQ & Y & ETR \\
\hline \multirow[t]{3}{*}{$\mathrm{CK}$} & TDM & $0.98 *$ & $0.99 * *$ & 0.50 & $0.96 *$ & $1.00 * *$ & $0.98 *$ & 0.81 & 0.50 \\
\hline & TFM & 0.66 & 0.59 & $1.00 * *$ & 0.24 & 0.41 & 0.65 & 0.91 & $1.00 * *$ \\
\hline & $\mathrm{R} / \mathrm{S}$ & -0.67 & -0.6 & $-1.00 * *$ & -0.26 & -0.43 & -0.67 & -0.92 & -1.00 ** \\
\hline \multirow[t]{3}{*}{ G } & TDM & $0.98^{*}$ & 0.36 & 0.92 & 0.12 & $1.00 * *$ & 0.48 & $0.99 * *$ & 0.47 \\
\hline & TFM & 0.30 & $0.96^{*}$ & 0.48 & $1.00 * *$ & 0.14 & 0.91 & 0.19 & 0.92 \\
\hline & $\mathrm{R} / \mathrm{S}$ & -0.16 & 0.73 & 0.03 & 0.88 & -0.32 & 0.64 & -0.27 & 0.64 \\
\hline \multirow[t]{3}{*}{$\mathrm{T}$} & TDM & 0.94 & 0.93 & 0.74 & 0.89 & 0.80 & 0.77 & $1.00 * *$ & 0.32 \\
\hline & TFM & 0.92 & 0.91 & 0.78 & 0.86 & 0.76 & 0.73 & $0.99 * *$ & 0.27 \\
\hline & $\mathrm{R} / \mathrm{S}$ & -0.80 & -0.79 & -0.91 & -0.71 & -0.58 & -0.54 & -0.94 & -0.03 \\
\hline \multirow[t]{3}{*}{ S } & TDM & $0.96^{*}$ & $1.00 * *$ & 0.89 & $0.99 * *$ & 0.84 & $0.96^{*}$ & 0.86 & 0.89 \\
\hline & TFM & 0.79 & 0.90 & 0.65 & 0.88 & 0.58 & 0.79 & 0.60 & 0.65 \\
\hline & $\mathrm{R} / \mathrm{S}$ & -0.81 & -0.92 & -0.68 & -0.89 & -0.61 & -0.81 & -0.63 & -0.68 \\
\hline \multirow[t]{3}{*}{$\mathrm{G}+\mathrm{S}$} & TDM & $0.97 *$ & 0.85 & 0.90 & 0.89 & 0.40 & 0.38 & 0.92 & 0.90 \\
\hline & TFM & $0.99 *$ & 0.79 & 0.85 & 0.83 & 0.50 & 0.47 & 0.87 & 0.85 \\
\hline & $\mathrm{R} / \mathrm{S}$ & $-0.96^{*}$ & -0.86 & -0.91 & -0.90 & -0.37 & -0.35 & -0.93 & -0.91 \\
\hline \multirow[t]{3}{*}{$\mathrm{T}+\mathrm{S}$} & TDM & 0.39 & $1.00 * *$ & 0.59 & 0.66 & 0.04 & 0.28 & 0.85 & 0.90 \\
\hline & TFM & 0.73 & 0.94 & 0.87 & 0.30 & 0.44 & 0.65 & 0.56 & 0.65 \\
\hline & $\mathrm{R} / \mathrm{S}$ & -0.77 & -0.92 & -0.90 & -0.24 & -0.49 & -0.70 & -0.51 & -0.61 \\
\hline \multirow[t]{3}{*}{$\mathrm{M}+\mathrm{S}$} & TDM & 0.94 & 0.49 & $0.98^{*}$ & 0.91 & 0.81 & 0.86 & $0.96^{*}$ & $0.99 *$ \\
\hline & TFM & 0.93 & 0.50 & $0.98^{*}$ & 0.91 & 0.81 & 0.87 & $0.96^{*}$ & $0.98^{*}$ \\
\hline & $\mathrm{R} / \mathrm{S}$ & $-0.97 *$ & -0.39 & $-0.95^{*}$ & $-0.95^{*}$ & -0.88 & -0.80 & $-0.99 *$ & $-1.00 * *$ \\
\hline
\end{tabular}

$g_{\mathrm{s}}, \mathrm{L}_{\mathrm{s}}, \mathrm{q}_{\mathrm{p}}, \mathrm{NPQ}, \mathrm{Y}$, and ETR. In $\mathrm{S}$, TDM showed significant positive correlations with $P_{\mathrm{N}}, g_{\mathrm{s}}$, WUE, and NPQ. In G+S, TDM and TFM showed a significant positive correlation with $P_{\mathrm{N}}$. In $\mathrm{T}+\mathrm{S}$, TDM showed a significant positive correlation with $g_{s}$. In $\mathrm{M}+\mathrm{S}$, TDM and TFM showed significant positive correlations with $\mathrm{L}_{\mathrm{s}}$, Y, and ETR.

\section{Discussion}

In plants, as in many other organisms, soluble sugars are essential primary metabolites. They play major roles as regulatory molecules controlling gene expression, plant physiology, metabolism, the cell cycle, and plant development (Koch 1996, Paul and Foyer 2001, Gibson 2005). The most common and significant effect of salt stress in non-halophytes is the inhibition of growth. Soil salinization is widely prevalent; thus, considerable attention has been paid to the study of salt resistance in plants. The effects of exogenous sugars on seedling growth seem to be complex. Glucose and sucrose are known to inhibit photosynthesis and seedling development at high concentrations, such as $300 \mathrm{mM}$ (Koch 1996, Zhou 1998), but low to moderate concentrations of sugars can enhance the growth of Arabidopsis plantlets in terms of Chl accumulation and root growth (Paul and Foyer 2001, Gibson et al. 2001, Martin et al. 2002, Sulmon et al. 2004, 2006). Baena-González and Sheen (2008) found that glucose and sucrose, as soluble sugars, acted as signals controlling maize responses to biotic and abiotic stress. Boriboonkaset (2007) found that exogenous sucrose and glucose as the main carbon source in the culture media of rice played a direct role in stimulating growth and development and functioned as a defense mechanism against salt stress. However, systematic studies of the ability of exogenous sugars to alleviate the inhibitory effects caused by salt stress in triticale were lacking until this study.

Our results were similar to those of previous studies; the root fresh mass and dry mass of triticale decreased under salt stress, the pretreatment with glucose and sucrose could maintain or enhance these traits, and the pretreatment with mannitol did not relieve the reductions of root fresh mass and dry mass. Schmildt et al. (2015) found that the increased production of papaya dry biomass was caused by the application of an exogenous carbon source. Campostrini et al. (2008) also found that shoot dry matter was increased by sucrose in the culture medium. Roots are the first parts affected by excessive salinity; reduction of root growth and alteration of development induced by salinity have been observed in many plant species (Córdoba et al. 2001, Cavalcanti et al. 2007, Farissi et al. 2013, Yan et al. 2016). Salt stress also reduces shoot growth by suppressing leaf initiation and expansion, as well as internode growth, and by accelerating leaf senescence and abscission. Salt stress rapidly reduces the leaf growth rate (Munns 1993) due to a reduction in the number of elongating cells and/or the 
rate of cell elongation (Szalai and Janda 2009). Our study showed that the root-to-shoot ratio in triticale decreased under salt stress, and application of glucose, sucrose, and mannitol reduced this salt stress damage. Exogenous glucose and sucrose enhanced the salt resistance of plants and promoted growth and dry matter accumulation. The same concentration of mannitol did not cause this effect; it showed that the ameliorating effect of exogenous sugar on salt stress does not occur because of osmosis.

Salt stress influences photosynthesis due to the reduction in Chl content (Kiani-Pouya and Rasouli 2014). Salt stress may have a deleterious impact on chloroplasts due to the influx of $\mathrm{Na}^{+}$and $\mathrm{Cl}^{-}$, which directly exert toxic effects, resulting in the degradation of Chl (Kiani-Pouya and Rasouli 2014). Parvaneh et al. (2012) found that, in plant resistance against salinity, increasing the proline, sugar, and $\mathrm{Chl}$ contents in leaves is useful for retaining and improving photosynthetic performance in plants. Exogenous applications of such agents enhanced the Chl contents in maize and soybean (Mason et al. 1928). Sulmon et al. (2004) found that both glucose and sucrose promoted $\mathrm{Chl}$ accumulation in some mutant seedlings, particularly, at lower $(40 \mathrm{mM})$ concentrations, compared to growth in the absence of sugars. This effect had been previously observed by Gibson et al. (2001), who reported that a $150 \mathrm{mM}$ sucrose treatment increased $\mathrm{Chl}$ content. Sugars accumulated in leaves have direct effects on the expression of photosynthetic genes and Chl. Zhang et al. (2005) found that compared with non-transgenic plants, transgenic plants accumulated more trehalose, maintained their Chl content, and showed enhanced tolerance to salt. In this paper, the results are consistent with those of previous studies. Our results showed that glucose and sucrose can increase the $\mathrm{Chl}$ content and promote photosynthesis in triticale under normal conditions. Glucose and sucrose can alleviate the damage to chlorophyll caused by salt stress and maintain or enhance photosynthesis.

PSII is considered the primary site of injury to the photosynthetic apparatus during the stress and senescence processes (Sharkey et al. 2010). PSII injury can lead to obvious changes in Chl fluorescence. Chl fluorescence has been used as a powerful and reliable method for assessing changes in the function of PSII and for assessing the primary photosynthetic processes under environmental stress conditions (Maxwell and Johnson 2000, Hajiboland et al. 2010). Analysis of Chl fluorescence parameters allows insights into the status of PSII. Stress applied to green plants, which directly or indirectly affects the photosynthetic metabolism, is likely to change the yield of Chl fluorescence (Dabrowski et al. 2017). PSII efficiency in light, electron transport chain efficiency, the efficiency of PSII open reaction centers in light, and the maximum quantum yield of PSII were reduced, while nonphotochemical quenching increased during salt stress (He et al. 2009, Zhang et al. 2009). Some studies have shown that exogenous agents improve the efficiency of PSII in different plants during stress or senescence. Sulmon et al. (2004) found that exogenous sucrose induced the expression of the $p s b A$ gene to support rapid repair of PSII function. We found that the application of glucose and sucrose to triticale seedlings caused increases in $F_{m}$, $\mathrm{F}_{\mathrm{v}} / \mathrm{F}_{\mathrm{m}}, \mathrm{Y}, \mathrm{ETR}$, and decreases in $\mathrm{F}_{0}$, under salt stress. The $\mathrm{F}_{\mathrm{v}} / \mathrm{F}_{\mathrm{m}}$ value is a measure of accumulated photo-oxidative damage to PSII (Garg et al. 2002); under optimal growth conditions, this ratio is approximately 0.85 in many plants, but it markedly declines during stress. For the regulatory mechanism of improving Chl fluorescence of photoncounting histogram (PSII), a reasonable explanation is the increase of the Chl content. Our study showed that compared to $\mathrm{S}, \mathrm{q}_{\mathrm{P}}$ was higher and NPQ was lower in $\mathrm{G}+\mathrm{S}$ and $\mathrm{T}+\mathrm{S}$, while NPQ was higher in $\mathrm{M}+\mathrm{S}$, which indicated that glucose and sucrose can enhance the resistance of triticale. The increased excitation energy dissipated in the form of heat (NPQ) to protect the photosynthetic apparatus from damage.

The results obtained from our study showed that $P_{\mathrm{N}}$, $g_{\mathrm{s}}, C_{\mathrm{i}}, E$, WUE, and $\mathrm{WUE}_{\mathrm{i}}$ decreased under salt stress. Salinity decreases the availability of $\mathrm{CO}_{2}$ at its fixation site due to the impacts of toxic ions $\left(\mathrm{Na}^{+}\right.$and $\left.\mathrm{Cl}^{-}\right)$on the photosynthetic apparatus and the disturbances in the function of leaf stomata (Reddy et al. 1998). In addition, $P_{\mathrm{N}}$ can be affected by stomatal or nonstomatal factors (Farooq et al. 2009). The decrease in the photosynthetic rate seems to result from $\mathrm{CO}_{2}$ limitation since $C_{\mathrm{i}}$ was reduced with the imposition of salt stress. When sucrose was omitted from the culture medium and the medium was enriched with $\mathrm{CO}_{2}$, Khan et al. (2002) detected photosynthetic carbon assimilation in all assessment periods.

The application of exogenous sugar can mitigate salt injury. Siringam et al. (2012) found that exogenous sucrose could effectively improve photosynthesis in rice under salt stress. These previous results are consistent with our report here, where the application of glucose and sucrose increased $P_{\mathrm{N}}$ and $C_{\mathrm{i}}$ and delayed the reduction rate of $E$ and $g_{s}$, compared to S. Zhang et al. (2016) also found that adding glucose significantly enhanced the growth rate and carrying capacity of Ochromonas compared to photoautotrophic growth and that photosynthesis also increased with the application of glucose during the exponential growth stage.

Conclusion: Salt stress inhibited growth and reduced photosynthesis in triticale, causing a reduction in biomass. The application of glucose and sucrose alleviated the injury caused by salt stress, increasing SPAD value, F, $\mathrm{F}_{\mathrm{v}} / \mathrm{F}_{\mathrm{m}}, \mathrm{F}_{\mathrm{m}}, P_{\mathrm{N}}$, and $C_{\mathrm{i}}$. These sugars also decreased NPQ, $\mathrm{L}_{\mathrm{s}}$, and $\mathrm{WUE}_{\mathrm{i}}$, reduced the decrease in $\mathrm{F}_{0}, E$, and $g_{\mathrm{s}}$ and improved photosynthetic capacity, resulting in a greater fresh and dry matter accumulation.

\section{References}

Akram K.A., Mohammad H.N., Mohammad H., et al.: Salt effects on seed germination and seedling emergence of two Acacia species. - Afr. J. Plant Sci. 5: 52-56, 2011.

Araya T., Noguchi K., Terashima I.: Effects of carbohydrate accumulation on photosynthesis differ between sink and source leaves of Phaseolus vulgaris L. - Plant Cell Physiol. 47: 644-652, 2006.

Arzani A.: Improving salinity tolerance in crop plants: a 
biotechnological view. - Vitro Cell. Dev. Biol. Plant. 44: 373383, 2008.

Baena-González G.E., Sheen J.: Convergent energy and stress signaling. - Cell 12: 1360-1385, 2008

Baker N.R.: Chlorophyll fluorescence: a probe of photosynthesis in vivo. - Annu. Rev. Plant Biol. 59: 89-113, 2008.

Baque M.A., Elgirban A., Lee E.J. et al.: Sucrose regulated enhanced induction of anthraquinone, phenolics, flavonoids biosynthesis and activities of antioxidant enzymes in adventitious root suspension cultures of Morinda citrifolia (L.). - Acta Physiol. Plant. 34: 405-415, 2011.

Boriboonkaset T., Bunyajinda V., Chaum S. et al.: Effect of exogenous sugar classes and concentrations on salt-tolerant ability of indica rice (Oryza sativa L.). - Acta Horticul. 746: 155-163, 2007.

Bray E.A., Bailey-Serres J., Weretilnyk E: Responses to a biotic stresses in biochemistry and molecular biology of plants. Am. Soc. Plant Physiol. chybi issue: 1158-1249, 2000.

Campostrini E., Mothé G.P.B., Torres N.A. et al.: Photochemical efficiency and growth characteristics of sugar cane (Saccharum officinarum L.) plants cultivated in vitro under different sucrose concentrations and light quality. - Plant Cell Cult. Micro. 4: 84-91, 2008.

Cavalcanti F.R., Lima J.P.M., Ferreira-Silva S.L. et al.: Roots and leaves display contrasting oxidative response during salt stress and recovery in cowpea. - J. Plant Physiol. 164: 591600, 2007.

Córdoba A., Seffino L.G., Moreno H. et al.: Characterization of the effect of high salinity on roots of Chloris gayana Kunth carbohydrate and lipid accumulation and growth. - Grass Forage Sci. 56:162-168, 2001.

Dabrowski P., Kalaji M.H., Baczewska A.H. et al.: Delayed chlorophyll a fluorescence, MR 820, and gas exchanges in perennial ryegrass under salt stress. - J. Lumin. 183: 322-333, 2017.

Demmig-Adams A.B., Adams W.W.III, Baker D.H. et al.: Using chlorophyll fluorescence to assess the fraction of absorbed light allocated to thermal dissipation of excess excitation. Physiol. Plantarum 98: 253-264, 1996.

Farissi M., Ghoulam C., Bouizgaren A.: Changes in water deficit saturation and photosynthetic pigments of alfalfa populations under salinity and assessment of proline role in salt tolerance.Agric. Sci. Res. J. 3: 29-35, 2013.

Farooq M., Wahid A., Kobayashi N. et al.: Plant drought stress: effects, mechanisms and management. - Agron. Sustain. Dev. 29: 185-212, 2009.

Garg A.K., Kim J.K., Owens T.G. et al.: Trehalose accumulation in rice plants confers high tolerance levels to different abiotic stresses. - Appl. Biol. Sci. 99: 15898-15903, 2002.

Gibson S.I.: Control of plant development and gene expression by sugar signalling. - Curr. Opin. Plant Biol. 8: 93-102, 2005.

Gibson S.I., Laby R.J., Kim D.: The sugar-insensitive1 (sis1) mutant of Arabidopsis is allelic to ctr1. - Biochem. Biophys. Res. Co. 280: 196-203, 2001.

Hajiboland R., Aliasgharzadeh N., Laiegh S.F. et al.: Colonization with arbuscular mycorrhizal fungi improves salinity tolerance of tomato (Solanum lycopersicum L.) plants. - Plant Soil 331: 313-327, 2010.

He Y., Zhu Z., Yang J. et al.: Grafting increases the salt tolerance of tomato by improvement of photosynthesis and enhancement of antioxidant enzymes activity. - Environ. Exp. Bot. 66: 270278, 2009.

Hu H., Liu W., Fu Z. et al.: QTL mapping of stalk bending strength in a recombinant inbred line maize population. Theor. Appl. Genet. 126: 2257-2266, 2013.

Khan V., Kozai T., Nguyen Q.T. et al.: Growth and net photo- synthetic rates of Eucalyptus tereticornis Smith under photomixotrophic and various photoautotrophic micropropagation conditions. - Plant Cell Tiss. Org. Cult. 71: 141146, 2002.

Kiani-Pouya A., Rasouli F.: The potential of leaf chlorophyll content to screen bread-wheat genotypes in saline condition. - Photosynthetica 52: 288-300, 2014.

Koch K.E.: Carbohydrate-modulated gene expression in plants. Annu. Rev. Plant Phys. 47: 509-540, 1996.

Li X.B., Wan S.Q., Kang Y.H. et al.: Chinese rose (Rosa chinensis) growth and ion accumulation under irrigation method to reclaim heavy coastal saline soils. - Agr. Water Manage.158: 99-111, 2015.

Liang Y.C., Si J., Nikolic M. et al.: Organic manure stimulates biological activity and barley growth in soil subject to secondary salinization. - Soil Biol. Biochem. 37: 1185-1195, 2005.

Liu L.P., Long X.H., Shao H.B. et al.: Ameliorants improve saline-alkaline soils on a large scale in northern Jiangsu Province, China. - Ecol. Eng. 81: 328-334, 2015.

Martin T., Oswald O., Graham I.A.: Arabidopsis seedling growth, storage lipid mobilization, and photosynthetic gene expression are regulated by carbon: nitrogen availability. Plant Physiol. 128: 472-481, 2002.

Mason T.G., Maskell E.J.: Studies on the transport of carbonhydrates in the cotton plant: I. A study of diurnal variation in the carbohydrates of leaf, bark, and wood, and of the effects of ringing. - Ann. Bot.-London 42: 189-253, 1928.

Maxwell K., Johnson G.N.: Chlorophyll fluorescence - a practical guide. - J. Exp. Bot. 51: 659-668, 2000.

Monje O.S., Bugbee B.: Inherent limitations of nondestructive chlorophyll meters: a comparison of two types of meters. Sci. Hortic.-Amsterdam 27: 69-71, 1992.

Mortain-Bertrand A., Stammitti L., Telef N. et al.: Effects of exogenous glucose on carotenoid accumulation in tomato leaves. - Physiol. Plantarum 134: 246-256, 2008.

Muchembled, Sahraoui L.H., Grandmoughin-Ferjani A. et al.: Changes in lipid composition of Blumeriagraminis f.sp. triticiconidia produced on wheat leaves treated with heptanoyl salicylic acid. - Phytochemistry 67: 1104-1109, 2006.

Munns R.: Physiological processes limiting plant growth in saline soils: Some dogmas and hypotheses. - Plant Cell Environ. 16: 15-24, 1993.

Munns R., James R.A., Läuchli A.: Approaches to increasing the salt tolerance of wheat and other cereals. - J. Exp. Bot .57: 1025-1043, 2006.

Munns R.: Coparative physiology of salt and water stress. - Plant Cell Environ. 25: 239-250, 2002.

Parvaneh R., Shahrokh T., Seyed M.H.: Studying of salinity stress effect on germination, proline, sugar, protein, lipid and chlorophyll content in purslane (Portulaca oleracea L.) leaves. - J. Physiol. Bioch. 8: 182-193, 2012.

Paul M.J., Foyer C.H.: Sink regulation of photosynthesis. - J. Exp. Bot .52: 1383-1400, 2001.

Pego J.V., Kortstee A.J., Huijser C. et al.: Photosynthesis, sugars and the regulation of gene expression. - J. Exp. Bot. .51: 407416, 2000.

Rasouli F., Kiani-Pouya A.: Photosynthesis capacity and enzymatic defense system as bioindicators of salt tolerance in triticale genotypes. - Flora 214: 34-43, 2015.

Reddy P.S., Ramanjulu S., Sudhakar C. et al.: Differential sensitivity of stomatal and non-stomatal components to $\mathrm{NaCl}$ or $\mathrm{Na}_{2} \mathrm{SO}_{4}$ salinity in horsegram, Macrotyloma uniflorum (Lam). - Photosynthetica 35: 99-105, 1998.

Reignault P.H., Cogan A., Muchembled J. et al:: Trehalose induces resistance to powdery mildew in wheat. - New 
Phytol. 149: 519-529, 2001

Samad R., Karmoker J.L.: Effects of gibberellic acid and kinetin on seed germination and accumulation of $\mathrm{Na}^{+}$and $\mathrm{K}^{+}$in the seedlings of triticale-I under salinity stress. - Bangladesh J. Bot. 41: 123-129, 2012.

Samad R., Karmoker J.L.: Effects of $\mathrm{NaCl}$ stress on accumulation of $\mathrm{K}^{+}, \mathrm{Na}^{+}, \mathrm{Cl}^{-}, \mathrm{NO}^{3-}$,sugar and proline contents in the seedings of triticale-I. - Bangladesh J. Bot. 42: 189-194, 2013.

Schmildt O., Torress-Netto A., Schmildt E.R. et al.: Photosynthetic capacity, growth and water relations in 'Golden' papaya cultivated in vitro with modifications in light quality, sucrose concentration and ventilation. - Theor. Exp. Plant Physiol. 27: $7-18,2015$

Setia R, Gottschalk P, Smith P et al: Soil salinity decreases global soil organic carbon stocks. - Sci. Total Environ. 465: 267$272,2013$.

Sharathchandra R.G., Sudisha J., Mostafa A. et al.: Exogenous trehalose treatment enhances the activities of defense-related enzymes and triggers resistance against downy mildew disease of pearl millet. - Front. Plant Sci. .7: 1593, 2016.

Sharkey T.D., Zhang R.: High temperature effects on electron and proton circuits of photosynthesis. - J. Integr. Plant Biol. 52: 712-722, 2010.

Siringam K, Juntawong N., Cha-um S.: Salt tolerance enhancement in indica rice (Oryza sativa L.) seedlings using exogenous sucrose supplementation. - Plant Omics J. 5: 52-59, 2012.

Smeekens S., Ma J., Hanson J. et al.: Sugar signals and molecular networks controlling plant growth. - Curr. Opin. Plant Biol. 13: 1-6, 2009.

Sulmon C., Gouesbet G., Coue'e I.: Sugar-induced tolerance to atrazine in Arabidopsis seedlings: interacting effects of atrazine and soluble sugars on psbA mRNA and D1 protein levels. - Plant Sci. 167: 913-923, 2004.

Sulmon C., Gouesbet G., El Amrani A.: Sugar induced tolerance to the herbicide atrazine in Arabidopsis seedlings involves activation of oxidative and xenobiotic stress responses. -
Plant Cell Rep. 25: 489-498, 2006.

Szalai G., Janda T.: Effect of salt stress on the salicylic acid synthesis in young maize (Zea mays L.) plants. - J. Agron. Crop Sci. 195: 165-171, 2009.

Tayeh C., Randoux B., Vincent D. et al.: Exogenous trehalose induces defences in wheat before and during abiotic stress caused by powdery mildew. - Phytopathology 104: 293-305, 2014.

Teng T., Zhai L.H., Liu R.X. et al.: ZmGA3ox2, a candidate gene for a major QTL, qPH3.1, for plant height in maize. - Plant J. 73: 405-416, 2013.

Trouvelot S., Héloir M.C., Poinssot B. et al.: Carbohydrates in plant immunity and plant protection: roles and potential application as foliar sprays. - Front. Plant Sci. 5: 592, 2014.

Yan K., Xu H., Zhao S. et al.: Saline soil desalination by honeysuckle (Lonicera japonica Thunb.) depends on salt resistance mechanism. - Ecol. Eng. 88: 226-231, 2016.

Yin C., Berninger F., Li C.: Photosynthetic responses of Populus przewalski subjected to drought stress. - Photosynthetica 44: 62-68, 2006.

Zhang L., Li B.P., Wu Z.Q. et al: Changes in growth and photosynthesis of mixotrophic Ochromonas sp. in response to different concentrations of glucose. - J. Appl. Phyco. 28: 2671-2678, 2016.

Zhang R., Sharkey T.D.: Photosynthetic electron transport and proton flux under moderate heat stress. - Photosynth. Res. 100: 29-43, 2009.

Zhang S.Z., Yang B.P., Feng C.L. et al.: Genetic transformation of tobacco with the trehalose synthase gene from Grifola frondosa Fr. enhances the resistance to drought and salt in tobacco. - J. Integr. Plant Biol. 47: 579-587, 2005.

Zhou L., Jang J.C., Jones T.L. et al.: Glucose and ethylene signal transduction crosstalk revealed by an Arabidopsis glucoseinsensitive mutant. - Proc. Natl. Acad. Sci. USA. 95: 1029410299, 1998.

(C) The authors. This is an open access article distributed under the terms of the Creative Commons BY-NC-ND Licence. 